\title{
Self-care support for the management of type 1 diabetes during the transition from childhood to adolescence*
}

\author{
Autocuidado apoiado no manejo da diabetes tipo 1 durante \\ a transição da infância para adolescência \\ Autocuidado apoyado en el manejo de la diabetes tipo 1 durante \\ la transición de la infancia a la adolescencia
}

Neusa Collet ${ }^{1}$, Annanda Fernandes de Moura Bezerra Batista ${ }^{2}$, Vanessa Medeiros da Nóbrega ${ }^{2}$, Maria Helena do Nascimento Souza ${ }^{2}$, Leiliane Teixeira Bento Fernandes ${ }^{3}$

How to cite this article:

Collet N, Batista AFMB, Nóbrega VM, Souza MHN, Fernandes LTB. Self-care support for the management of type 1 diabetes during the transition from childhood to adolescence. Rev Esc Enferm USP. 2018;52:e03376. DOI: http://dx.doi.org/10.1590/S1980-220X2017038503376

* Extracted from the Scientific Initiation Project: "Condições crônicas na infância: cuidado na atenção primária à saúde", com o plano chamado "Necessidade de autocuidado apoiado à criança com diabetes tipo 1 na transição da infância para a adolescência", Universidade Federal da Paraíba, 2016-2017.

${ }^{1}$ Universidade Federal da Paraíba, Departamento de Enfermagem em Saúde Coletiva. Programa de Pós-graduação em Enfermagem. João Pessoa, PB, Brazil.

${ }^{2}$ Universidade Federal da Paraíba. João Pessoa, PB, Brazil.

${ }_{3}^{3}$ Universidade Federal do Rio de Janeiro, Escola de Enfermagem Anna Nery. Departamento de Enfermagem de Saúde Pública, Rio de Janeiro, RJ, Brazil.

\section{ABSTRACT}

Objective: To analyze the needs of pre-adolescents with type 1 diabetes regarding selfcare support for disease management. Method: Qualitative study conducted between October and December 2016 with pre-adolescents seen at a hospital outpatient clinic and at Family Health Units; semi-structured interviews were used. Data were analyzed using a thematic analysis based on the theoretical basis of self-care support. Results: Nine pre-adolescents participated in the study. It was identified that in order to build self-efficacy, pre-adolescents need to overcome the disease denial phase, know how to handle feelings triggered by the need for lifestyle changes, receive support from their families and social networks, and have the self-awareness and self-perception needed to feel secure in managing their diabetes. Conclusion: The intrinsic challenges of adolescence and the way pre-adolescents with diabetes handle the disease have an influence on diabetes management and create needs that must be appreciated by health care professionals in order to provide self-care support.

\section{DESCRIPTORS}

Diabetes Mellitus, Type 1; Adolescent; Self Care; Pediatric Nursing; Child Care.
Corresponding author:

Annanda Fernandes de Moura Bezerra Batista

Rua Etelvina Macedo de Mendonça, 630 Apto 1704 B. Torre

CEP 58040-530 - João Pessoa, PB, Brazil

annanda.fernandes@gmail.com
Received: 09/26/2017

Approved: 05/08/2018 


\section{INTRODUCTION}

Diabetes is one of the most common diseases among all age groups; 415 million people worldwide live with this chronic condition. In Brazil, the number of cases among children and adolescents aged 0 to 14 years is $30,900^{(1)}$. The transition phase to adolescence can be a risk factor for inadequate treatment adherence and disease management, affecting quality of life ${ }^{(2)}$.

For pre-adolescents, disease management is related to the development of self-care and self-efficacy, how much they know about the disease, their school routines and their support from friends, family members and the professionals monitoring their treatment ${ }^{(2)}$.

Thus, in this transition phase from childhood to adolescence, which is characterized by a crucial period of physiological, sexual, intellectual, psychological and social transformations that leads individuals to rebuild their ideas, thoughts, self-image and self-perception, some difficulties in the management of diabetes can be expected. These arise from questioning and feelings, including denial, escape, anger, depression, acceptance, shyness, apathy, conflicts and $\mathrm{crises}^{(3)}$; these are characteristic of this life stage of the diabetic child who, accordingly, needs support.

In addition to the transition inherent to this age range, diabetic pre-adolescents undergo another transition phase related to disease management. The transfer of disease management from the family to the pre-adolescent, who gradually takes increasing responsibility for self-care, often does not coincide with the maturity of the pre-adolescent's selfefficacy, especially when the disease management transfer occurs prematurely ${ }^{(4)}$.

Self-efficacy is defined as a person's belief in their own ability to produce performance that influences life events. This belief is created through cognitive, affective, motivational and selection processes that influence how the person feels, thinks, motivates themselves and behaves ${ }^{(5)}$. In this context, pre-adolescents with diabetes require special attention in both transition processes in order to build self-efficacy.

In Brazil, the care of individuals with chronic diseases is regulated by Health Care Networks (HCNs), which aim to prevent fragmented care and ensure that all actions taken and services provided are effective and efficient ${ }^{(6)}$ in order to provide continued and integral care. From this perspective, it is important to strengthen relationships between users and health care teams in order to develop teams that define problems and goals and establish care plans that can be adjusted when necessary. This action planning strategy is known as self-care support, and it refers to offering systematized care that focuses on educational and interventional actions to empower individuals to perform self-care, increasing the potential value of the care provided to individuals with chronic diseases by connecting them with social and group support, educational projects, information and resources in order to support and improve their self-care ${ }^{(7)}$.

Self-care support provides an opportunity for the individual to assume a leading role in their own health care. It typically involves five steps: 1) evaluation - identification of knowledge, behaviors, social life and health history; 2) counseling - transmission of constructive information and health education; 3 ) agreement - collaborative elaboration of the self-care plan based on information obtained during the evaluation phase; 4) identification of barriers, motivations and involvement; and 5) follow-up - determining the most effective form of monitoring according to the user's profile ${ }^{(7)}$. Thus, this process is crucial to the work of the Family Health Strategy (FHS) professionals who work with this population.

In view of the numerous demands discussed above, which require professional support in both transition phases - from childhood to adolescence and from the family providing care to the pre-adolescent with type 1 diabetes (T1D) providing self-care - the question that needs to be asked is, which self-care needs - supported in the management of T1D during the transition from childhood to adolescence - need to be assisted by the HCN from the perspective of the preadolescent? These needs must be recognized by the relevant academic and health care groups in order to be considered from the perspective of care. Thus, the objective of the present study was to analyze the needs for self-care support in disease management among pre-adolescents with T1D.

\section{METHOD}

This is a qualitative descriptive exploratory study with self-care support as the theoretical framework. Nine preadolescents with T1D seen at the outpatient clinic of a university hospital and at the ESF units of five Health Districts (HDs) from a municipality in Paraíba, Brazil, participated in the study.

In the present study, pre-adolescence was considered the biological period between 10 and 14 years of age in which there is an acceleration in development ${ }^{(8)}$. The following inclusion criteria were adopted: having a diagnosis of T1D, an age between 10 and 14 years, and receiving care from a family member over 18 years of age. Those with cognitive and/or communication difficulties were excluded.

\section{Data collection}

Data were collected between October and December of 2016. Initially, ESFs were chosen by lottery, with at least one ESF represented per HD among the five that comprise the municipal network. However, due to difficulties in finding preadolescents with T1D in the drawn units, direct contact was sought with the professionals from the ESFs in any of the HDs.

After individuals who met the inclusion criteria were identified, access to participants in the ESFs was mediated by a community health agent, who accompanied the researcher to the interviewee's residence. In the outpatient clinic of the reference hospital, the pre-adolescents who were registered in the area of coverage of any ESF in Paraiba state were approached after consultations with the specialist. When each interview took place, only the researcher and the pre-adolescent were present. It is notable that all of the pre-adolescents who were approached agreed to participate in the study. 
Semi-structured interviews were used for the data collection. These were recorded using an electronic device, lasted 25 to 55 minutes, and were guided by the following leading questions: Tell me about the day-to-day care of your diabetes at home. How does your family help you with your diabetes care? Do you receive any help from health care professionals? How would you describe this help? When you are at school, how do you manage your diabetes? This step was concluded when theoretical saturation was reached, i.e., when the researcher found that the information became repetitive such that including further interviewees would not add new value to the topic since the objective of the study had been achieved ${ }^{(9)}$.

\section{DatA ANALYSIS}

Empirical data were interpreted using a thematic analysis. For this purpose, the interviews were transcribed in full and successively re-read, and the material was evaluated to choose data that were relevant to the objective of the study. The most significant words or expressions were then searched for and grouped into clusters of meaning ${ }^{(10)}$. From these clusters, interpretations were conducted and the following thematic categories were constructed: overcoming the disease denial phase; coping with feelings triggered by the need for lifestyle changes; receiving support from the family and social network; having the knowledge and self-perception needed to feel confident managing diabetes.

\section{ETHICAL ASPECTS}

The present study was guided by Resolution 466/12 of the Brazilian National Health Council and was approved under protocol n. 054/14 and CAAE n. 27102214.6.0000.5188 on July 21, 2016. Consent for the interviews was obtained from the family caretakers via signatures on informed consent forms and via the informed assent of the minors. The anonymity of the participants was ensured by using the acronym "PA" for the pre-adolescent followed by a chronological number based on the order in which the interviews were conducted along with each participant's age.

\section{RESULTS}

Charts 1 and 2 show the characteristics of the nine study participants and the thematic categories constructed.

Chart 1 - Characterization of the pre-adolescents in terms of age, sex, school grade, time since diagnosis and complications - João Pessoa, Paraíba, Brazil, 2016.

\begin{tabular}{|c|c|c|c|c|c|}
\hline Participant & Age (years) & Sex & Grade & Time since diagnosis & Complications \\
\hline PA1 & 12 & $\mathrm{~F}$ & $7^{\text {th }}$ & 4 years & - \\
\hline PA2 & 10 & $M$ & $5^{\text {th }}$ & 6 years and 6 months & - \\
\hline PA3 & 11 & M & Illiterate & 8 years & - \\
\hline PA4 & 14 & $\mathrm{~F}$ & $9^{\text {th }}$ & 3 years & Renal dysfunction \\
\hline PA5 & 14 & $\mathrm{~F}$ & $9^{\text {th }}$ & 2 months & - \\
\hline PA6 & 13 & $\mathrm{~F}$ & $8^{\text {th }}$ & 4 years & - \\
\hline PA7 & 10 & $M$ & $5^{\text {th }}$ & 6 years & - \\
\hline PA8 & 13 & $M$ & $8^{\text {th }}$ & 4 months & - \\
\hline PA9 & 11 & $\mathrm{~F}$ & $6^{\text {th }}$ & 1 year and 5 months & - \\
\hline
\end{tabular}

Chart 2 - Characterization of the pre-adolescents in terms of their municipality of origin, caretaker educational level, health insurance and frequency of visits to the Family Health Unit (FHU) - João Pessoa, Paraíba, Brazil, 2016.

\begin{tabular}{|l|c|c|c|c|}
\hline Participant & Municipality of origin & Caretaker educational level & Health insurance & Visits to FHU \\
\hline PA1 & João Pessoa & Incomplete BE* & - & - \\
\hline PA2 & Pedras de Fogo & Incomplete HS* & - & $2 \times$ every 3 months \\
\hline PA3 & Duas Estradas & Illiterate & - & Yes \\
\hline PA4 & João Pessoa & Completed HS* & - & $2 \times$ every 3 months \\
\hline PA5 & João Pessoa & Completed HS* & $2 \times$ every 3 months \\
\hline PA6 & João Pessoa & Completed HE* & - & - \\
\hline PA7 & João Pessoa & Incomplete HS* & - & $2 \times$ every 3 months \\
\hline PA8 & João Pessoa & Incomplete HS* & - & $2 \times$ every 3 months \\
\hline PA9 & João Pessoa & Completed HS* & - & 2 \\
\hline
\end{tabular}

*BE = basic education; $\mathrm{HS}$ = high school; $\mathrm{HE}=$ higher education. 


\section{OverComing THE DISEASE DENIAL PHASE}

Denial of the disease in the transition phase from childhood to adolescence was exhibited by some study participants, for example, by self-affirmation of considering oneself "normal":

Ifeel normal (...) like, my father has it, my cousin has it, so I feel like I am (not) a diabetic person. It doesn't seem like I have it; that's why I wanted to live near them (PA9, 11a).

I don't like to talk about my feelings with respect to diabetes. I feel normal, so I see no need for it (PA5, 14a).

Another form of denial was hiding the diagnosis from their group of friends out of fear of being discriminated or excluded:

I don't take my diabetes materials to school because I am ashamed of taking them out in the classroom, and the guys start telling everybody (PA9, 11a).

My friends don't know that I have diabetes. I'm embarrassed to tell them because I think they'll think I'm weird and they'll laugh at me (PA7, 10a).

This type of non-acceptance may be related to the stigma and/or stereotypes people have regarding the disease:

I don't like it when people pity me because I have diabetes (PA6, 13a).

Diabetes is not contagious. Why do people keep saying they don't want to touch me to avoid catching diabetes, or that they won't kiss me so their mouth won't fill with ants? (PA4, 14a).

This reality had a negative influence on how diabetes was perceived by the pre-adolescents:

In this disease, you can't go too many hours without an injection. It's awful, it's agonizing. I wish I didn't have diabetes (PA3, 11a).

I was really sad when I got my diagnosis (...) (PA9, 11a).

\section{COPING WITH FEELINGS TRIGGERED BY THE NEED FOR LIFESTYLE CHANGES}

Feelings of sadness were cited when pre-adolescents referred to restrictions on sugary foods and how to cope with them:

It's very bad, because you can't even eat sweets. I feel sad because I can't eat sweet things, so I go eat something salty so I'm not so sad (PA8, 11a).

When I get sad because I can't eat sweets, I ask my mom to buy my favorite fruit (PA9, 11a).

Living with restrictions and changing habits was also connected with the fear of future complications due to uncontrolled disease; this was also based on perceptions of the situations their peers were in:

I understand that diabetes is no joke because it can cause blindness and you can lose a kidney (PA1, 12a).

When I see my father on hemodialysis, with blood coming out of his neck, I know that I have to take care of myself so I don't end up like him (PA9, 11a).

\section{RECEIVING SUPPORT FROM THE FAMILY AND SOCIAL} NETWORK

The family also experiences stress with respect to the new dynamics imposed by diabetes. Thus, the caretaker's ability to manage the disease affects how the child copes with it:

My mother needs help controlling my diabetes. She needs somebody to help her with her nervousness. This is sometimes bothersome, because once she left the needle hanging in me. This leaves us all anxious (PA8, 11a).

During this process, family support is crucial, since it can help make day-to-day life with the disease less painful: I feel like this, well, because I know that there are people taking care of me (...) my aunt, my grandmother, my father and my mother are everything to me in this situation (PA4,14a).

My family is always telling me important things so I don't give up and continue doing things right... controlling diabetes (...) I feel well. I feel happy, because my family is concerned about me (PA8, 11a).

Despite positive family support, the pre-adolescents wanted health care professionals to be part of their social network, to support them and to help them cope with difficult situations:

I'd want a professional to help me keep going on, despite the prejudice, to help me overcome it and not be bothered by it (PA4, 14a).

I think that if there was a professional helping me with my shame of saying that I have diabetes, I'd control it better (PA9, 11a).

In addition to professional support, the pre-adolescents reported the importance of being with their peers, as this allows for a vision of the future based on the positive experiences lived by others:

I'd like to engage with other people who have diabetes. A new experience. Because when you know an adolescent who's going through the same problems as you, you know there are many people going through the same thing and that you are not the only one (PA1, 12a).

I feel good being among people with diabetes. It helps knowing that older people managed to have a good life, (...) so you can, too (PA6, 13a).

\section{HAVING ENOUGH KNOWLEDGE AND SELF-PERCEPTION TO FEEL CONFIDENT MANAGING DIABETES}

T1D management methods are adapted according to the maturity and experience of each pre-adolescent, and any difficulty overcome becomes a victory:

The first times, it was very difficult. I wondered if someday I'd get used to the new routine, because the first time, it hurt a lot. But, after the other times, the pain began to lessen, so now I take (insulin) and it seems normal. It has become a routine (...) I feel very good about having managed it the right way (PA4, 14a).

The support received by the pre-adolescents in the process of developing self-care skills was essential to achieving autonomy and independence in the safe management of the condition: 
When she (mother) did it (administered insulin), I couldn't go out much, because I depended on her for the injections. Now I know how to do it. I feel free... liberated (PA6, 13a).

Being able to inject insulin by myself is a victory in my life... before that, I was really afraid of that needle. Now I am familiar with it, and that's good for me (PA8, 11a).

Knowledge of the disease and positive self-perceptions allowed the pre-adolescents to build self-efficacy, which resulted in greater safety in the management of diabetes and in overcoming fears and situations of prejudice that were present in their social interactions:

Today I have freedom. You're not afraid of talking about diabetes, can handle the prejudice better; the answer is at the tip of the tongue. I explain what the disease is like, its types, and that it's not contagious. Knowing oneself and knowing the disease helps a lot for socializing in everyday life. Today I know that I can have a good life and get there if I control it (PA6, 13a).

\section{DISCUSSION}

In this study, certain things were found in the transition phase from childhood to adolescence that influenced the needs presented by the pre-adolescents with respect to adequate disease management, and these needs must be appreciated by health care professionals.

With self-care support, pre-adolescents with T1D can assume a leading role in their care, rendering this approach effective in preparing this population for the management of their own health during the transition from childhood to adolescence ${ }^{(4)}$.

Through follow-up care, the professional, together with the adolescent and the family, can detect the challenges of everyday life with a chronic disease and create interventions to assist the adolescent with self-care. Specifically, this refers to coping with social exclusion, perceptions of the disease in everyday life, self-perception, self-efficacy maturity and the ability of parents to provide support and gradually share responsibilities with the pre-adolescent according to their capacity, encouraging the pre-adolescent to assume them ${ }^{(11)}$. In this cyclical follow-up process, the professional identifies the needs that arise over time in order to support the preadolescent's self-care skills.

Feelings and behaviors were identified that could interfere with the control of diabetes. These arose from challenges inherent to the way the pre-adolescents experienced their everyday lives and were found during the evaluation as the first stage of self-care support.

These challenges can give rise to disease-related grief, which includes the stages of denial, anger, bargaining, depression and acceptance ${ }^{(12)}$, as highlighted in the categories of disease denial and lifestyle changes. By considering the stages of the evaluation and of the accompanying self-care support, the health care professional has the opportunity to identify factors that lead to disease denial, distorted selfperception, shame, fear and sadness in order to understand the subjectivity involved in the management of diabetes and to support the pre-adolescent in coping with these issues, considering that they interfere with building self-efficacy, i.e., in believing in one's ability to positively change life events to maintain one's health.

One of the desires that was common to two thematic categories was wanting to be among peers, that is, with other people with the same disease. However, the participants had two different perspectives on this, one related to disease denial and the other to sharing experiences. The former was expressed by the desire to live with family members who have diabetes, since the shared needs for care gives them a sense of "being normal". This form of disease denial is consistent with findings from a study conducted in Zambia in which "being normal"was detected as negative coping, since the adolescents not only felt different from others but also remained alone in this journey when around others with the same condition ${ }^{(13)}$.

The desire to not want to talk about the topic was related to non-acceptance of the diagnosis and, at the same time, to confused self-perception, because there was resistance against incorporating disease management into everyday life. This need always requires support from the health care team. In contrast, pre-adolescents who had already been through the stage of denial wanted to be with people from their social network with the same disease in order to share experiences that would support them in their self-care.

In this study, impaired self-perception, as evidenced by the desire to not want to live with the disease due to shame, reinforces subjective processes of denial and require special attention by the health care team. Furthermore, the distorted ideas expressed by classmates with regard to diabetes kept the pre-adolescents from perceiving them as a source of support, and this can interfere with self-perception among pre-adolescents with T1D. These results are in agreement with those of a study conducted in Brazil that stated that disease-related stigma can be one of the major factors leading to shame and, thus, concealment of the diagnosis. This can trigger insecurity and difficulty socializing and can interfere with self-care among pre-adolescents ${ }^{(14)}$.

Pre-adolescents hide their diabetes diagnoses from their friends out of fear of exclusion and because they feel different from their peers ${ }^{(4,15)}$. This becomes a stressful situation that can compromise the empowerment gained from self-care ${ }^{(16)}$. Denial towards peers was permeated with fear of eventually losing their social group during an important stage in life. Thus, pre-adolescents need to be supported by health care professionals through accurate and sensitive evaluations in this process in order to overcome difficulties.

A lack of knowledge about diabetes among peers can generate disrespectful attitudes. This situation is associated with a lack of structure and educational events in school environments to promote the inclusion of students with diabetes, which reinforces this discrimination ${ }^{(16-17)}$. Thus, identifying situations of bullying during the evaluation stage is vital to planning interventions for effective self-care support for pre-adolescents in school.

The pre-adolescents described the disease as something bad because it requires dietary restrictions and the injection of insulin, among other measures needed for disease management. This is evidence of a need to adjust to the condition of being a 
diabetic and its required lifestyle changes. The literature ${ }^{(16,18-19)}$ confirms these factors by showing that these changes in routine are prone to provoking feelings of sadness, anger, fear, unhappiness or distress. These are commonly observed at the time of diagnosis and can lead to inefficient management strategies.

In the category coping with feelings triggered by the need for lifestyle changes, diabetes management and dietotherapy were identified as the most common difficulties in the everyday lives of the pre-adolescents; both of these can be considered part of the assistance stage. This is due to the need to rebuild eating habits and monitor the intake of sugary foods, which are their favorites.

In the stage of counseling and establishing an agreement, the interdisciplinary health care team uses educational strategies to reduce the frustration and anger felt by preadolescents for wanting and not being able to consume the foods that are commonly consumed by their non-diabetic peers ${ }^{(20-21)}$. Due to the dietary restrictions of diabetes, preadolescents use the strategy of substituting their preferred foods. However, this alone is not enough sometimes, and the pre-adolescents need help from health care professionals to create more effective strategies.

In addition to the changes in everyday life due to diabetes, the results of this study show that concern about and fear of disease-related complications and previous negative experiences lived by them or by family members due to poor knowledge of the disease can have a negative impact on the lives of pre-adolescents with T1D. One study ${ }^{(4)}$ found that, as a result of pre-adolescents not receiving adequate support in the transition phase from childhood to adolescence, many of them focused on negative aspects and difficulties of coping with the management of the disease, which led to obstacles to addressing their therapeutic needs.

Even though pre-adolescents understand the risks of insufficient glucose control and the complications that can result from it, what motivated them to control their glucose levels was the fear of dying rather than a desire to improve their quality of life. In the transition phase from childhood to adolescence, the fear of dying can become a stress factor in disease management ${ }^{(13)}$, making emotional support from family necessary. However, family members are sometimes not prepared to offer positive support, as was shown in the section addressing family support.

Specifically, pre-adolescents expressed feelings of fear and insecurity when their family was not prepared to help them with coping, which can cause a delay in the adolescent assuming a leading role in self-care. These findings are in agreement with a Brazilian study ${ }^{(11)}$ that showed that a caretaker's attitudes, stress and insecure behavior with respect to diabetes management could affect self-care.

Thus, a lack of knowledge and skills regarding disease management and therapeutic procedures on the caretaker's part weakens the potential support the family can offer to the pre-adolescent and has a negative influence on building the pre-adolescent's self-care skills ${ }^{(20-22)}$.

In contrast, some pre-adolescents reported positive feelings towards the emotional support received from family members and stressed that this support was crucial in their acceptance of the disease. The advice, positive thinking and therapeutic management received from the caregiving family members transformed the way the adolescents perceived the task of glucose control.

However, in the category receiving support from the family and social network, an impact was found in the phase of the transition of care from the family to the adolescent when self-care support was not provided by a multiprofessional health team. This impact is related to psychological changes that tend to negatively impact metabolic control. A study from Australia ${ }^{(12)}$ corroborates this finding.

From this perspective, another study ${ }^{(23)}$ recognized the pre-adolescent as a unique being who yearns to be welcomed, supported and involved with members of their social network, i.e., family members, friends, neighbors and health care professionals, among others, to help them cope with the everyday needs and difficulties that can arise from living with a chronic disease such as T1D.

As part of the support network, the multiprofessional health team works with the family throughout the pre-adolescent's follow-up care and helps them improve their coping and management skills, adapt them to the challenges of the disease and aid in the identification of emotional challenges ${ }^{(16)}$. Thus, together with the pre-adolescent, the multiprofessional team can establish plans with the family to gradually prepare the pre-adolescent for adequate diabetes control in order to minimize risks and ensure maintenance of their health ${ }^{(24)}$.

In the interdisciplinary context, the nurse must be able to identify disease-related emotional problems beyond the time of diagnosis. The pre-adolescent needs to understand their health condition, and the nurse must help them create coping strategies ${ }^{(15-16)}$. Thus, it is necessary to apply a method that promotes the pre-adolescents' active participation in the process of assuming a leading role in their own care and that stimulates them to reflect on their situation.

However, as observed in previous research, poor support by the health care team in the basic health network can delay the acceptance of the diagnosis and hamper the development of autonomy and independence for self-care ${ }^{(19)}$. Similar results were found in this study, as the pre-adolescents noted the absence of a professional who could help them overcome difficulties imposed by T1D in their transitional periods.

Some pre-adolescents expressed a desire to have the opportunity to share experiences with peers. A previous study ${ }^{(23)}$ emphasized the value of group therapy as a form of multiprofessional intervention since it allows individuals with the same disease to interact and share their common experiences. This interaction can be a positive support for diabetes control by allowing pre-adolescents to exchange advice on how to handle challenging self-care situations. Additionally, it can promote self-reflection and motivate them to obtain more knowledge ${ }^{(21)}$.

During follow-up care, the multiprofessional team can work on maturing self-efficacy among pre-adolescents by making them believe in their own potential to positively transform their experienced events. This maturing process entails acceptance of diabetes and thus promotes the idea that the limitations imposed by the disease need not 
make them feel different from other adolescents, therefore minimizing the feeling of exclusion and favoring their selfesteem and independence ${ }^{(25)}$.

The present study corroborates the results of previously cited studies by showing that self-efficacy and the rebuilding of self-perception allow pre-adolescents to know themselves, to obtain deeper knowledge needed to understand their disease and to integrate self-care into their everyday lives, not as something bad or a cause to fear death but rather to improve their quality of life.

The autonomy praised by the pre-adolescents, which is monitored through follow-up care, has been described as the ability to be in charge of one's own body and to cope with prejudice and stigma within a social group of similar-aged peers. This reality reflects better control of the disease and the self-confidence needed to explain what diabetes is and to not feel shame over treating it, such as through managing blood sugar control and administering insulin.

Building this autonomy from self-efficacy and rebuilding self-perception by accepting the disease engenders a balance between diabetes management in everyday life and the changes required during this transition phase. These findings are confirmed by a study conducted in the United States ${ }^{(26)}$, which found in the adolescents' acceptance of the disease an outlet for the obstacles identified in managing it. This occurred through promoting an understanding that they will live with diabetes and that changes are necessary to ensure quality of life, as is coping with the disease to reduce fear, to learn how to manage it and to receive adequate support. Based on this, adolescents adopt a new notion of "normal"(26) and have a new meaning to their own existence.

Independence and autonomy in diabetes management among the pre-adolescents studied resulted in freedom, satisfaction and happiness because they perceived themselves as capable of taking care of themselves when they managed their own therapy and treatment. They felt they did not depend completely on others but also did not refuse the constant support they needed in this process. Self-confidence, as identified in the reports of the study participants, enhanced the desire to perform self-care and their openness to discussing the disease without fearing prejudice and exclusion.
One of the limitations of this study is the small number of participants, which does not allow the results to be generalized. However, this study broadens the understanding of factors involved in the need for self-care support for diabetes management during the transitional phases from childhood to adolescence and of diabetes care from the family to the preadolescent. This shows the need for adequate support by the health care team, family members and friends in order to ensure effective self-care support in these different stages. In addition to being a way of managing care, self-care support facilitates the systematization of the care provided to children, pre-adolescents and adolescents with chronic diseases and their families.

\section{CONCLUSION}

This study showed that self-care support needs for the management of T1D in pre-adolescents arise from how they cope with the disease in their everyday lives. The need for accurate and sensitive evaluations of the different modalities of disease denial, feelings triggered by lifestyle changes, support from the family and other members of the social network, knowledge about the disease and self-perception of the pre-adolescent with T1D were identified. All of these needs influence self-care in the management of diabetes.

Emotional overload, of both the pre-adolescents and their families, was also identified as a factor that can weaken disease management. The transition from childhood to adolescence, together with the beginning of the transferring of care responsibilities from the family to the child with T1D, can lead to stress due to the demands of new care plans and changes in routines, schools, and internal and external conflicts.

Gaps were found in support needs for self-care. This includes support by the multiprofessional health team and other members of the social network, such as the pre-adolescent's school and friends. This lack of support can extend the pre-adolescent's process of disease denial and affect disease management.

Self-care support, in all of its stages, can be an important tool for the identification of the needs of pre-adolescents in both transition phases. These needs must be considered in the plan for the implementation of more effective plans that favor the maturing of self-efficacy to achieve autonomy in the management of T1D.

\section{RESUMO}

Objetivo: Analisar as necessidades de pré-adolescentes com diabetes tipo 1 para o autocuidado apoiado no manejo da doença. Método: Pesquisa qualitativa, realizada entre outubro e dezembro de $2016 \mathrm{com}$ pré-adolescentes atendidos em um ambulatório hospitalar e em Unidades de Saúde da Família, utilizando-se de entrevista semiestruturada. Os dados foram analisados por meio da análise temática, à luz do referencial teórico de autocuidado apoiado. Resultados: Participaram da pesquisa nove pré-adolescentes. Identificou-se que, para a construção da autoeficácia, os pré-adolescentes necessitam superar a fase de negação da doença; saber lidar com os sentimentos desencadeados pela necessidade de mudanças no estilo de vida; receber apoio familiar e da rede social; e ter conhecimento e autopercepção adequados para se sentirem seguros no manejo da diabetes. Conclusão: Evidenciou-se que os desafios intrínsecos à adolescência e o modo como os pré-adolescentes com diabetes lidam com a doença em seu cotidiano influenciam o manejo da diabetes e ocasionam necessidades que devem ser valorizadas pelos profissionais da rede de cuidado por meio do apoio para o autocuidado.

\section{DESCRITORES}

Diabetes Mellitus Tipo 1; Adolescente; Autocuidado; Enfermagem Pediátrica; Cuidado da Criança.

Objetivo: Analizar las necesidades de preadolescentes con diabetes tipo 1 para el autocuidado apoyado en el manejo de la enfermedad. Método: Investigación cualitativa, llevada a cabo entre octubre y diciembre de 2016 con preadolescentes atendidos en un ambulatorio 
hospitalario y en Unidades de Salud de la Familia, utilizándose entrevista semiestructurada. Los datos fueron analizados mediante el análisis temático, a la luz del marco de referencia teórico de autocuidado apoyado. Resultados: Participaron en la investigación nueve preadolescentes. Se identificó que, para la construcción de la autoeficacia, los preadolescentes necesitan superar la fase de negación de la enfermedad; saber manejar los sentimientos desencadenados por la necesidad de cambios en el estilo de vida; recibir apoyo familiar y de la red social; y tener conocimiento y autopercepción adecuados para sentirse seguros en el manejo de la diabetes. Conclusión: Se evidenció que los retos intrínsecos a la adolescencia y el modo cómo los preadolescentes con diabetes manejan la enfermedad en su cotidiano influyen en el cuidado de la diabetes y ocasionan necesidades que los profesionales de la red de cuidado deben valorizar por medio del apoyo para el autocuidado.

\section{DESCRIPTORES}

Diabetes de Tipo 1; Adolescente; Autocuidado; Enfermería Pediátrica; Cuidado Del Niño.

\section{REFERENCES}

1. International Diabetes Federation. IDF Diabetes Atlas [Internet]. Brussels: IDF; 2016 [cited 2017 Jan 2]. Available from: http://www. diabetesatlas.org

2. Malaquias TSM, Marques CDC, Faria ACP, Pupulim JSL, Marcon SS, Higarashi IH. The division of the care of the child or adolescent with type I diabetes with the family. Cogitare Enferm. 2016;21(1):1-7. DOI: 10.5380/ce.v21i4.42010

3. Casey BJ. Beyond simple models of self-control to circuit-based accounts of adolescent behavior. Annu Rev Psychol. 2015;66:295-319. DOI: 10.1146/annurev-psych-010814-015156

4. Commissariat PV, Kenowitz JR, Trast J, Heptulla RA, Gonzalez JS. Developing a personal and social indentity with type 1 diabetes during adolescence: a hypothesis generative study. Qual Health Res. 2016;26(5):672-84. DOI: 10.1177/1049732316628835

5. Bandura A. Self-efficacy. In: Ramachaudran VS, editor. Encyclopedia Human Behavior [Internet]. New York: Academic Press; 1994 [cited 2018 Jan 30]. Available from: http://www.uky.edu/ eushe2/Bandura/Bandura1994EHB.pdf

6. Brasil. Ministério da Saúde; Secretaria de Atenção à Saúde, Departamento de Atenção Básica. Estratégias para o cuidado da pessoa com doença crônica. Brasília: MS; 2014. (Cadernos de Atenção Básica, 35).

7. Mendes EV. O cuidado das condições crônicas na atenção primária à saúde: o imperativo da consolidação da Estratégia da Saúde da Família. Brasília: Organização Pan-Americana de Saúde; 2012.

8. World Health Organization. Young people's health: a challenge for society. Report of a WHO Study Group on young people and "Health for All by the Year 2000" [Internet]. Geneva: WHO; 1986 [cited 2018 Jan 30]. Available from: http://apps.who.int/iris/handle/10665/41720

9. Minayo MCS, Assis SG, Souza ER. Avaliação por triangulação de métodos: abordagem dos programas sociais. Rio de Janeiro: Fiocruz; 2014.

10. Minayo MCS. O desafio do conhecimento: pesquisa qualitativa em saúde. São Paulo: Hucitec; 2014.

11. Silva MEA, Moura FM, Albuquerque TM, Reichert APS, Collet N. Network and social support in children with chronic diseases: understanding the child's perception. Texto Contexto Enferm [Internet]. 2017 [cited 2017 Jan 12];26(1):e6980015. Available from: http:// www.scielo.br/scielo.php?script=sci_arttext\&pid=S0104-07072017000100317

12. Hackorth NJ, Hamilton VE, Moore SM, Northam EA, Bucalo Z, Cameron FJ. Predictors of diabetes self-care, metabolic control, and mental health in youth with type 1. Aust Psychol. 2013;48(5):360-8. DOI: 10.1111/ap.12007

13. Hapunda G, Abubakar A, Vijver FV, Pouwer F. Living with type 1 diabetes is challenging for Zambian adolescents: qualitative data on stress, coping with stress and quality of care and life. BMC Endocr Disord [Internet]. 2015 [cited 2017 Jan 11];15:20. Available from: https:// www.ncbi.nlm.nih.gov/pmc/articles/PMC4411790/

14. Sparapani Vde C, Jacob E, Nascimento LC. What is it like to be a child with type 1 diabetes mellitus? Pediatr Nurs. 2015;41(1):17-22.

15. Rostami S, Parsa-Yekta Z, Ghezeljeh TN, Vanaki Z. Supporting adolescents with type 1 diabetes mellitus: a qualitative study. Nurs Health Sci. 2014;16(1):84-90. DOI: 10.1111/nhs.12070

16. Kakkar J, Puri S. Psychosocial implications of type 1 diabetes mellitus among children in India: an emerging challenge for social work profession. Open J Psychiatry Allied Sci. 2016;7(2):103-10. DOI: 10.5958/2394-2061.2016.00016.1

17. Jackson CC, O'Neill AA, Butler KL, Chiang JL, Deeb LC, Hathaway K, et al. Diabetes care in the school setting: a position statement of the American Diabetes Association. Diabetes Care. 2015;38(10):1958-63. DOI: 10.2337/dc15-1418

18. Lowes L, Eddy D, Channon S, McNamara R, Robling M, Gregory JW. The experience of living with type 1 diabetes and attending clinic from the perception of children, adolescents and carers: analysis of qualitative data from the depicted study. J Pediatr Nurs. 2015;30(1):5462. DOI: $10.1016 /$ j.pedn.2014.09.006

19. Dieter T, Lauerer J. Depression or diabetes distress? Perspect Psychiatr Care. 2018;54(1):84-7. DOI: 10.1111/ppc.12203

20. Koller D, Khan N, Barret S. Pediatric perspectives on diabetes self-care: a process of achieving acceptance. Qual Health Res. 2014;25(2):26475. DOI: $10.1177 / 1049732314551057$

21. Bertin RL, Elizio NPS, Morais RNT, Medeiros CO, Fiori LS, Ulbrich AZ. Percepções do cotidiano alimentar de crianças e adolescentes com diabetes mellitus tipo 1. Rev Contexto Saúde [Internet]. 2016 [citado 2017 jan. 12];16(30):100-9. Disponível em: https://www.revistas. unijui.edu.br/index.php/contextoesaude/article/view/5665

22. Nóbrega VM, Silva MEA, Fernandes LTB, Viera CS, Reichert APS, Collet N. Chronic disease in childhood and adolescence: continuity of care in the Health Care Network. Rev Esc Enferm USP. 2017;51:e03226. DOI: http://dx.doi.org/10.1590/S1980-220X2016042503226

23. Pennafort VPS, Queiroz MVO, Nascimento LC, Guedes MVC. Network and social support in family care of children with diabetes. Rev Bras Enferm. 2016;69(5):856-63. DOI: 10.1590/0034-7167-2015-0085 
24. Whithead LC, Trip HT, Hale LA, Conder J. Negotiated autonomy in diabetes self-management: the experiences of adults with intellectual disability and their support workers. J Intellect Disabil Res. 2016;60(4):389-97. DOI: 10.1111/jir.12257

25. Venancio JMP, La Banca RO, Ribeiro CA. Benefits of participation in a summer camp to self-care for children and adolescents with diabetes: the perception of mothers. Esc Anna Nery. 2017;21(1):e20170004. DOI: 10.5935/14148145.20170004

26. Babler E, Strickland CJ. Helping adolescents with Type 1 Diabetes "Figure It Out". J Pediatr Nurs. 2016;31(2):123-3. DOI: 10.1016/j/ pedn.2015.10.007

Financial support

Conselho Nacional de Desenvolvimento Científico e Tecnológico (CNPq). Scholarship from the Institutional Scientific Initiation Scholarship Program (Programa Institucional de Bolsas de Iniciação Científica - PIBIC). Process no. 474762/2013-0. 